\title{
Lung cancers attributable to environmental tobacco smoke and air pollution in non-smokers in different European countries: a prospective study
}

Paolo Vineis*1,32, Gerard Hoek², Michal Krzyzanowski³ ${ }^{3}$ Federica VignaTaglianti $^{4}$, Fabrizio Veglia ${ }^{4}$, Luisa Airoldi ${ }^{5}$, Kim Overvad ${ }^{6}$, Ole RaaschouNielsen ${ }^{7}$, Francoise Clavel-Chapelon ${ }^{8}$, Jacob Linseisen ${ }^{9}$, Heiner Boeing10, Antonia Trichopoulou ${ }^{11}$, Domenico Palli12, Vittorio Krogh ${ }^{13}$, Rosario Tumino ${ }^{14}$, Salvatore Panico ${ }^{15}$, H Bas Bueno-De-Mesquita ${ }^{16}$, Petra H Peeters ${ }^{17}$, Eiliv Lund E18, Antonio Agudo ${ }^{19}$, Carmen Martinez ${ }^{20}$, Miren Dorronsoro ${ }^{21}$, Aurelio Barricarte ${ }^{22}$, Lluis Cirera ${ }^{23}$, J Ramon Quiros ${ }^{24}$, Goran Berglund 25, Jonas Manjer26, Bertil Forsberg27, Nicholas E Day ${ }^{28,}$ Tim J Key ${ }^{29}$, Rudolf Kaaks ${ }^{30}$, Rodolfo Saracci ${ }^{31}$ and Elio Riboli ${ }^{1}$

\begin{abstract}
Address: ${ }^{1}$ Imperial College London, London UK (Paolo Vineis: and University of Torino, Italy), ${ }^{2}$ Department of Environmental and Occupational Health, Utrecht University, Utrecht, The Netherlands, ${ }^{3}$ World Health Organization, European Centre for Environment and Health, Bonn, Germany, ${ }^{4}$ ISI Foundation, Turin, Italy, ${ }^{5}$ Istituto di Ricerche Farmacologiche Mario Negri, Milan, Italy, ${ }^{6}$ Department of Clinical Epidemiology, Aalborg Hospital, Aarhus University Hospital, Aalborg, Denmark, ${ }^{7}$ Institute of Cancer Epidemiology, Danish Cancer Society, Copenhagen, Denmark, ${ }^{8}$ INSERM, (Institut National de la Santé et de la Recherche Médicale), ERI 20, EA 4045, and Institut Gustave Roussy, Villejuif, F-94805, France, ${ }^{9}$ Division of Clinical Epidemiology, Deutsches Krebsforschungszentrum, Heidelberg, Germany, ${ }^{10}$ German Institute of Human Nutrition, PotsdamRehbücke, Germany, ${ }^{11}$ Department of Hygiene and Epidemiology, Medical School, University of Athens, Greece, ${ }^{12}$ Molecular and Nutritional Epidemiology Unit, and Molecular Biology Laboratory, CSPO-Scientific Institute of Tuscany, Florence, Italy, ${ }^{13}$ Department of Epidemiology, National Cancer Istitute, Milan, Italy, ${ }^{14}$ Cancer Registry, Azienda Ospedaliera "Civile M.P. Arezzo", Ragusa, Italy, ${ }^{15}$ Dipartimento di Medicina Clinica e Sperimentale, Università Federico II, Naples, Italy, ${ }^{16}$ Centre for Nutrition and Health, National Institute for Public Health and the Environment, Bilthoven, The Netherlands, ${ }^{17}$ Julius Center for Health Sciences and Primary Care, University Medical Center, Utrecht, The Netherlands, ${ }^{18}$ Institute of Community Medicine, University of Tromso, Norway, ${ }^{19}$ Department of Epidemiology, Catalan Institute of Oncology Barcelona, Consejería de Sanidad y Servicios Sociales, Spain, ${ }^{20}$ Andalusian School of Public Health, Granada, Spain, ${ }^{21}$ Department of Public Health of Guipuzkoa, San Sebastian, Spain, 22 Public Health Institute, Navarra, Spain, ${ }^{23}$ Department of Epidemiology, Regional Health Council, Murcia, Spain, ${ }^{24}$ Public Health and Health Planning Directorate, Asturias, Spain, ${ }^{25}$ Malmö Diet and Cancer Study, Lund University, Malmö, Sweden, ${ }^{26}$ Dept of Surgery, Malmö University Hospital, Malmö, Sweden, ${ }^{27}$ Department of Public Health and Clinical Medicine, University of Umeå, Sweden, ${ }^{28}$ MRC Dunn Human Nutrition Unit, Cambridge, UK, ${ }^{29}$ Cancer Research UK Epidemiology Unit, University of Oxford, UK, ${ }^{30}$ International Agency for Research on Cancer, Lyon, France, 31"IFC-National Research Council, Pisa, Italy" and 32Department of Epidemiology and Public Health, Imperial College London, St Mary's Campus, Norfolk Place, London W2 1PG, UK
\end{abstract}

Email: Paolo Vineis* - p.vineis@imperial.ac.uk; Gerard Hoek - G.Hoek@iras.uu.nl; Michal Krzyzanowski - MKR@ecehbonn.euro.who.int; Federica Vigna-Taglianti - fedevignataglianti@yahoo.com; Fabrizio Veglia - fveglia@isi.it; Luisa Airoldi - airoldi@marionegri.it; Kim Overvad - KO@DCE.AU.DK; Ole Raaschou-Nielsen - ole@cancer.dk; Francoise Clavel-Chapelon - clavel@igr.fr; Jacob Linseisen - J.Linseisen@dkfz-heidelberg.de; Heiner Boeing - Boeing@mail.dife.de; Antonia Trichopoulou - Antonia@nut.uoa.gr; Domenico Palli - d.palli@cspo.it; Vittorio Krogh - krogh@istitutotumori.mi.it; Rosario Tumino - Rtumino@tin.it; Salvatore Panico - spanico@unina.it; H Bas Bueno-De-Mesquita - HB.Bueno.de.mesquita@rivm.nl;

Petra H Peeters - P.H.M.Peeters@umcutrecht.nl; Eiliv Lund E - eiliv.lund@ism.uit.no; Antonio Agudo - a.agudo@ico.scs.es; Carmen Martinez - carmen.martinez.easp@juntadeandalucia.es; Miren Dorronsoro - m-dorronsoro@ej-gv.es; Aurelio Barricarte - ispepi01@cfnavarra.es; Lluis Cirera - Lluis.Cirera@carm.es; J Ramon Quiros - ramonqg@princast.es; Goran Berglund - Goran.berglund@medforsk.mas.lu.se; Jonas Manjer - jonas.manjer@smi.mas.lu.se; Bertil Forsberg - bertil.forsberg@envmed.umu.se; Nicholas E Day - Nick.day@srl.cam.ac.uk; Tim J Key - tim.key@ceu.ox.ac.uk; Rudolf Kaaks - kaaks@iarc.fr; Rodolfo Saracci - RODOLFO.SARACCI@recherche.univ-lyon1.fr; Elio Riboli - e.riboli@imperial.ac.uk * Corresponding author

Published: 15 February 2007

Environmental Health 2007, 6:7 doi:10.1 186/1476-069X-6-7
Received: 15 September 2006

Accepted: I5 February 2007 
This article is available from: http://www.ehjournal.net/content/6/I/7

(C) 2007 Vineis et al; licensee BioMed Central Ltd.

This is an Open Access article distributed under the terms of the Creative Commons Attribution License (http://creativecommons.org/licenses/by/2.0), which permits unrestricted use, distribution, and reproduction in any medium, provided the original work is properly cited.

\begin{abstract}
Background: Several countries are discussing new legislation on the ban of smoking in public places, and on the acceptable levels of traffic-related air pollutants. It is therefore useful to estimate the burden of disease associated with indoor and outdoor air pollution.

Methods: We have estimated exposure to Environmental Tobacco Smoke (ETS) and to air pollution in never smokers and ex-smokers in a large prospective study in 10 European countries (European Prospective Investigation into Cancer and Nutrition)(N = 520,000). We report estimates of the proportion of lung cancers attributable to ETS and air pollution in this population.

Results: The proportion of lung cancers in never- and ex-smokers attributable to ETS was estimated as between 16 and $24 \%$, mainly due to the contribution of work-related exposure. We have also estimated that 5-7\% of lung cancers in European never smokers and ex-smokers are attributable to high levels of air pollution, as expressed by $\mathrm{NO}_{2}$ or proximity to heavy traffic roads. $\mathrm{NO}_{2}$ is the expression of a mixture of combustion (traffic-related) particles and gases, and is also related to power plants and waste incinerator emissions.

Discussion: We have estimated risks of lung cancer attributable to ETS and traffic-related air pollution in a large prospective study in Europe. Information bias can be ruled out due to the prospective design, and we have thoroughly controlled for potential confounders, including restriction to never smokers and long-term ex-smokers. Concerning traffic-related air pollution, the thresholds for indicators of exposure we have used are rather strict, i.e. they correspond to the high levels of exposure that characterize mainly Southern European countries (levels of $\mathrm{NO}_{2}$ in Denmark and Sweden are closer to $10-20 \mathrm{ug} / \mathrm{m}^{3}$, whereas levels in Italy are around 30 or 40 , or higher).

Therefore, further reduction in exposure levels below $30 \mathrm{ug} / \mathrm{m}^{3}$ would correspond to additional lung cancer cases prevented, and our estimate of $5-7 \%$ is likely to be an underestimate. Overall, our prospective study draws attention to the need for strict legislation concerning the quality of air in Europe.
\end{abstract}

\section{Background}

From the point of view of public health it is important to estimate the burden of disease related to different air pollutants, in view of the new legislation that several countries are now introducing. Environmental tobacco smoke (ETS) and traffic-related air pollution share a few characteristics: they are widespread exposures in both the developed and the developing countries; they have several chemical components in common, in particular Polycyclic Aromatic Hydrocarbons; and they have been associated with increased risks of lung cancer and other diseases. The relative lung cancer increase is approximately of the same entity for both (around 20-30\%) [1-4]. However, no single prospective study has tried to assess the effects of both exposures in the same populations with accurate and standardized methods, and to estimate the total burden of lung cancer attributable to the two exposures.
We have estimated exposure to ETS and to air pollution in the context of the large EPIC study (European Prospective Investigation into Cancer and Nutrition), and here we report estimates of the attributable risks at the population level.

\section{Methods}

EPIC (European Prospective Investigation into Cancer and Nutrition) [5] is a multi-center European study, in which more than 520,000 healthy volunteers have been recruited in 10 European countries (Sweden, Denmark, Norway, Netherlands, UK, France, Germany, Spain, Italy, Greece) [6]. The cohort includes subjects of both genders, in the age range 35-74 at recruitment. Recruitment took place between 1993 and 1998. Dietary information on the frequency of consumption of more than 120 foods and drinks has been obtained by a Food Frequency Questionnaire, validated in a pilot phase. At enrollment, weight, 
height, waist and hip circumferences have been measured for each participant. Detailed information has been collected on reproductive history, physical activity, smoking and alcohol drinking history, medical history, occupation, education level and other socioeconomic variables; the questionnaire was printed in two separate versions for men and women. A computerized central database has been developed after checking, coding and quality control procedures.

The lifestyle questionnaire included several questions on smoking habits. Present exposure to environmental tobacco smoke (ETS) was investigated by a few questions: (a) exposure to ETS yes/no; (b) place of exposure (home, work); (c) number of hours of current exposure; (d) number of cigarettes smoked by the spouse in the presence of the index subject; (e) exposure to ETS during childhood. Only half of the EPIC centers (11/22) (in France, Italy, Denmark, Sweden, The Netherlands and Potsdam, Germany) included questions on ETS in the questionnaire, and most of these collected information only on items (a) or (b) above.

The EPIC cohort has been followed-up since inception through Cancer Registries, vital statistics (mortality), and - in some areas - hospital discharge data. Whenever available, diagnosis is based on histological confirmation. All incident cancers and all causes of death are registered and checked centrally.

We have also nested a case-control study on lung cancer (newly diagnosed after recruitment) within the EPIC cohort, aiming at studying the relationship with air pollution through individual exposure assessment (which was not feasible for the whole cohort). We included only never smokers or ex-smokers who quit at least 10 years before recruitment. We have matched three controls per case. Matching criteria were gender, age (plus or minus 5 years), smoking status, country of recruitment, and time elapsed between date of recruitment and date of diagnosis. Matching was introduced to allow strict control of potentially confounding variables, considering that other risk factors may be stronger than ETS or air pollution. The study has been approved by the Ethical Committee of the International Agency for Research on Cancer, and by all the local Ethical Committees of the participating centers.

Exposure to air pollution was assessed using concentration data from monitoring stations in routine air quality monitoring networks. We excluded traffic and industrial network sites and instead focused on urban or rural background locations, i.e. the site should be at least 50 meters away from any major road and at least 100 meters from a freeway and not located in an industrial area (preferably in a residential area). Data were obtained through search- ing AIRBASE, the air pollution database from the European Topic Center on Air Quality in Bilthoven [7]. In addition we contacted national/local monitoring agencies using a questionnaire and used Internet sites from national agencies. The average concentration for $\mathrm{O}_{3}, \mathrm{SO}_{2}$, $\mathrm{NO}_{2}$, CO and PM10 from all background monitoring stations in the city of residence was assigned to each study subject. For each home address we also assessed whether the home was located in a major street (yes/no). Several studies have documented substantial differences in concentration of traffic-related pollutants between traffic and background locations. For all homes, we used detailed Internet maps to evaluate whether the home was located in a major street (yes/no). Details are given in reference [8].

For ETS we have analyzed the whole cohort by Cox's proportional hazards model, using age as the dependent variable as suggested by Korn et al [9]. Hazard ratios (HR) were adjusted by gender, smoking habits (former or never smoker), time since recruitment, country, school years, energy intake, fruit and vegetables consumption, and physical activity. In the nested case-control study on air pollution we have computed odds ratios (OR) and 95\% confidence intervals (CI) in conditional logistic regression models [10] that included educational level (4 categories), as a further adjustment variable in addition to matching variables. We repeated the analyses using the center of recruitment and smoking duration/amount as additional adjustment variables. Analyses were performed with the SAS package (Cary, NC, USA) for a personal computer. Population attributable risks percent (PAR) were computed as:

\section{$\mathrm{G}(\mathrm{OR}-1) /(\mathrm{G}(\mathrm{OR}-1)+1)$}

where G is the proportion of exposed controls [11].

Details on main results, including cotinine measurements and information on genetic susceptibility, have been published previously $[6,8]$. Here we focus on the public health impact of both exposure to ETS and air pollution.

\section{Results}

Table 1 shows the prevalence of self-reported exposure to ETS in EPIC (whole cohort). An estimate between $40 \%$ and $60 \%$ can be reasonably considered as representative of most European countries, with the notable exception of Germany, with a much lower prevalence. These figures are comparable with those from other previous surveys $[4,12]$.

Table 2 shows hazard ratios for ETS and odds ratios for air pollution indicators. Concerning air pollution, we have found a statistically significant association only with 
Table I: Distribution of exposure to Environmental Tobacco Smoke in the EPIC cohort I

\begin{tabular}{lccc}
\hline & No & Yes & \% exposed \\
\hline France & 23821 & 35433 & 59.8 \\
Italy & 6953 & 13817 & 66.5 \\
The Netherlands & 7849 & 13474 & 63.2 \\
Germany & 19279 & 5592 & 22.5 \\
Sweden & 6673 & 15455 & 69.8 \\
Denmark & 10216 & 45786 & 81.8 \\
\hline
\end{tabular}

I: according to country (exposure at home and/or at work)

exposure to $\mathrm{NO}_{2}(\mathrm{OR}=1.30,95 \%$ CI $1.02-1.66)$. Estimates of the OR were 1.05 (95\% CI 0.65-1.69; greater or equal to $27 \mathrm{vs.} \mathrm{lower} \mathrm{than} 27 \mathrm{ug} / \mathrm{m}^{3}$ ) for PM10, and 1.15 (0.92-1.43; greater or equal to $11 \mathrm{vs.} \mathrm{lower} \mathrm{than} 11 \mathrm{ug} /$ $\mathrm{m}^{3}$ ) for $\mathrm{SO}_{2}$. The OR for $\mathrm{NO}_{2}$ was also adjusted for potential confounding from ETS by including cotinine levels in the logistic regression models. The cotinine-adjusted OR was 1.62 (95\% CI 0.92-1.43). Among never smokers the association with $\mathrm{NO}_{2}$ was represented by an OR of 1.09 (CI 0.78-1.52), while in ex-smokers the OR was 1.59 (1.10-2.30). Concerning ETS, the estimates were 1.05 for never smokers (0.60-1.82) and 2.32 for ex-smokers (0.94-5.71); after adjustment for smoking duration and number of cigarettes smoked the relative risk remained unchanged - for details see [6]. We found little heterogeneity among study centers, with a p-value for interaction with country of 0.94 for ETS and 0.76 for $\mathrm{NO}_{2}$. However, the sample size did not allow the estimation of risks for individual centers. The odds ratio for the joint exposure to both ETS and $\mathrm{NO}_{2}$ was as high as 4.51 , but the $\mathrm{CI}$ was very wide (0.46-43.48).

In previous publications we have shown more detailed analyses stratified by different characteristics of the cohort, but here we focus only on the main associations to estimate population attributable risks. On this basis we estimated for ETS an attributable proportion of $16 \%$ based on the analysis of the whole cohort. In fact, as shown before [6], the risk is mainly concentrated in workrelated exposures, with a higher attributable risk (around $24 \%)$. For air pollution, for which only the case-control data are available, the estimate is approximately $5-7 \%$ with both indicators used (heavy traffic road and $\mathrm{NO}_{2}$ greater than $30 \mathrm{ug} / \mathrm{m}^{3}$ ).

\section{Discussion}

A previous investigation estimated that approximately 7 per thousand cases of lung cancer could be attributed to ETS exposure in never smokers (spouses of smokers) [13]. Our figure is much larger, but it is based on both ex-smokers and never smokers. If we consider never smokers, the Hazard Risk estimate is 1.05 (95\% CI 0.60-1.82) and the attributable risk in the population is $2.5 \%$, still higher than the mentioned previous estimate. A likely explanation is that the above-mentioned study considered only exposure at home, whereas in our study the most important source of exposure, associated with higher risks, was exposure at work. The attributable risk for home exposure in our study, in fact, is 6 per thousand, in line with the previous estimate. In another recent study among never smokers only [14], the estimated OR was 1.31 (1.03$1.67)$ with a very high proportion of subjects who were ever exposed to ETS (86\%). This gives an attributable proportion as high as $21 \%$. When only exposure at home was considered, the OR was $1.19(1.01-1.40)$, the proportion exposed $48 \%$ and the PAR\% $8 \%$; for workplace exposure, OR $=1.11(0.94-1.31)$, proportion exposed 39\%, PAR\% $4 \%$.

Particularly concerning is the association between childhood exposure and the risk of lung cancer in adulthood (Table 2). As we have previously reported, there was a statistically significant trend $(\mathrm{p}=0.018)$ with increasing time of exposure to ETS in childhood, and with a hazard ratio of 3.63 (95\% CI 1.19-11.1211) for daily exposure for many hours [6]. To our knowledge, ours is the first prospective study to report such association $[15,16]$. Of course, the reliability of information on exposure to ETS in childhood can be questioned, although most people are expected to recall whether their parents smoked. The uptake of carcinogens by children exposed to ETS is widespread and quantitatively important [17]. Fetuses and newborns seem to be particularly susceptible to carcinogens. In one study, mother-newborn pairs exposed to high levels of indoor pollution from coal smoke were investigated [18]. For all markers, including DNA adducts, newborns had levels which were higher than in the mothers, although tranplacental exposure levels were 10-times lower than the paired mother exposures. In a series of well-designed experiments, Somers et al [19] reported increased mutation rates in herring gulls and mice exposed to air pollution at levels that characterize normal urban environments.

Our estimate of 5-7\% attributable to air pollution (measured as proximity to heavy traffic roads or exposure to $\mathrm{NO}_{2}$ ) is consistent with previous estimates from other authors [20]. However, both different exposure metrics and different pollutants have been used for previous estimates. In particular, Kunzli et al [21] used PM10, while estimates from the American Cancer Society (ACS) study [22] used PM2.5 as the reference pollutant. The ACS based the attributable risk calculation on a linear increase in PM2.5 in the $7.5-50 \mathrm{ug} / \mathrm{m}^{3}$ range. Unfortunately we do not have PM2.5 data in Genair, due to the sparse availability of such exposure parameter in Europe. Therefore, our estimate is compatible but not strictly comparable to 
Table 2: Hazard Ratios (HR) (whole cohort) and Odds Ratios (OR) (nested case-control study)'

\begin{tabular}{lcc}
\hline ETS & Hazard ratios & Controls: \\
\hline & & exposed/total \\
\hline $\begin{array}{l}\text { Exposure to ETS } \\
\text { at home and/or at work }\end{array}$ & $1.34(0.85$ to 2.13$)$ & $71722 / 123479$ (58\%) \\
PAR\% & 0.16 & \\
& & \\
ETS at work & $1.65(1.04$ to 2.63$)$ & $58653 / 123479(47 \%)$ \\
PAR\% & 0.24 & \\
ETS at home & $1.03(0.60$ to 1.76$)$ & $23396 / 123479(19 \%)$ \\
PAR\% & 0.006 & \\
ETS in childhood, daily (a) & $2.00(0.94$ to 4.28$)$ & $10282 / 60182(17 \%)$ \\
PAR\% & 0.14 & \\
Air pollution & & \\
Living near heavy & Odds ratios & \\
traffic road & & \\
PAR\% & $1.46(0.89-2.40)$ & $242 / 1990$ (I2\%) \\
Exposure to NO2 (b) & 0.05 & \\
PAR\% & $1.30(1.02-1.66)$ & $428 / 1562(27 \%)$ \\
\hline
\end{tabular}

(a) Reference category: never or seldom exposed to ETS in childhood; never smokers only

(b) more than $30 \mathrm{microgr} / \mathrm{m}^{3} \mathrm{vs}$. less than 30

I: $95 \%$ confidence intervals (in parenthesis) for ETS exposure (home and/or work), exposure to indicators of air pollution and lung cancer. Both OR and HR are adjusted by gender, age (plus or minus 5 years), smoking (former or never smoker), country, school years, energy intake, fruit and vegetable consumption, and physical activity. PAR\% = population attributable risk \% (see text).

the ACS estimate. Also, we did not find a clear association with PM10 in our data. $\mathrm{SO}_{2}$ as well (an indicator of longterm exposure to stationary combustion) was not associated in a statistically significant manner with lung cancer in our study, consistently with two Scandinavian lung cancer investigations $[23,24]$. A caveat is needed, i.e. we should consider that our cohort was never meant to be representative for the general population. This may be important especially for the estimates of the prevalence of relevant exposures. The PARs that we have computed apply to EPIC participants, but should be extrapolated with caution to lung cancer in non- and past smokers in the European population at large. However, the prevalence estimates we have computed in our study are, at least for ETS, realistic (with the exception of Germany) and similar to figures from other surveys. Another limitation of our study-related to the restriction to non-smokers - is the small number of subjects with the ensuing large confidence intervals of estimates.
We have excluded current smokers and recent ex-smokers. An interaction has been previously described between recent smoking and exposure to air pollution [25], but we were not able to address it; nor were we able to estimate the attributable risk due to the joint effect of the two exposures. This is clearly a limitation of our study, which, however, has the advantage of avoiding confounding through restriction to never and ex-smokers.

In summary, in our large prospective study we have found that among never smokers and ex-smokers since at least 10 years lung cancer was associated to self-reported ETS exposure at the time of recruitment. The proportion of lung cancers in never- and ex-smokers attributable to ETS was estimated as between 16 and $24 \%$, mainly due to the contribution of work-related exposure. Also exposure to ETS in childhood seemed to be associated with a relatively high proportion of lung cancers in adulthood; although this observation needs to be confirmed, it is particularly relevant for its public health implications. We have also found that higher exposure to some air pollutants (in particular $\mathrm{NO}_{2}$ ) can increase the risk of lung cancer in nonsmokers. We have thoroughly controlled for potential confounders. Information bias can be ruled out due to the prospective design. Changes in exposure levels are likely to have occurred after the cohort recruitment; this and other measurement errors are likely to lead to a blurring of the differences between cases and non-cases, i.e. to an underestimation of the strength of associations. The association with $\mathrm{NO}_{2}$ does not necessarily imply that this single pollutant is (more) carcinogenic than others, but could express the lower degree of exposure misclassification with $\mathrm{NO}_{2}$. The hypothesis that $\mathrm{NO} 2$ could better represent, at least in Europe, exposure to other pollutants, e.g. fine or ultrafine particles, has been extensively discussed, in particular in the recent revision of the WHO World Air Quality Guidelines [26]. We have estimated that 5-7\% of lung cancers in European never smokers and ex-smokers are attributable to high levels of air pollution, as expressed by $\mathrm{NO}_{2}$ or proximity to heavy traffic roads. The latter indicator has limitations, mainly related to the fact that it is associated to social class. It should be noticed that the thresholds for indicators of air pollution exposure we have used are rather strict, i.e. they correspond to the high levels of exposure that characterize mainly Southern European countries (levels of $\mathrm{NO}_{2}$ in Denmark and Sweden are closer to $10-20 \mathrm{ug} / \mathrm{m}^{3}$, whereas levels in Italy are around 30 or 40 , or higher). Therefore, further reduction in exposure levels below $30 \mathrm{ug} / \mathrm{m}^{3}$ would correspond to additional lung cancer cases prevented, and our estimate of 5$7 \%$ is likely to be an underestimate. Overall, our prospective study draws attention to the need for strict legislation concerning the quality of air in Europe. 


\section{Abbreviations}

- OR: odds ratios

- CI: confidence intervals

- PAR: population attributable risk

- ETS: environmental tobacco smoke

\section{Competing interests}

The author(s) declare that they have no competing interests.

\section{Authors' contributions}

All authors have read and approved the final version of this paper. All authors have directly participated in the planning, execution or analysis of the study:

PV, ER and RS carried out conception and design;

KO, O R-N, FC, HB, VK, DP, SP, RT, B B-De-M, PP GB, GH and PV carried out acquisition of data;

LA, FV, LO, RP, HA, AD, SG, EG, PH, CM, GM and MP carried out laboratory analyses, data analysis and interpretation of data;

PV drafted the article. He takes responsibility for the integrity of the data and the accuracy of the data analysis (guarantor).

\section{Acknowledgements}

This paper was made possible by a grant of the European Community (5th Framework Programme) to PV (grant QLK4CT 199900927), a grant from the European Union for the project ECNIS (WP4 and 8) to PV, and a grant of the Compagnia di San Paolo to the ISI Foundation. All authors are independent from funders. Mortality data for the Netherlands were obtained from "Statistics Netherlands". Also, the work described in the paper was carried out with the financial support of:

- Europe Against Cancer Program of the European Commission (SANCO)

- ISCIII, Red de Centros RCESP, C03/09

- Deutsche Krebshilfe

- Deutsches Krebsforschungszentrum

- German Federal Ministry of Education and Research

- Danish Cancer Society

- Health Research Fund (FIS) of the Spanish Ministry of Health

- Spanish Regional Governments of Andalucia, Asturias, Basque Country, Murcia and Navarra

- ISCII, Red de Centros RCESP(C09/03), Spain

\author{
- Cancer Research U.K. \\ - Medical Research Council, United Kingdom \\ - Stroke Association, United Kingdom \\ - British Heart Foundation \\ - Department of Health, United Kingdom \\ - Food Standards Agency, United Kingdom \\ - Wellcome Trust, United Kingdom Greek Ministry of Health \\ - Greek Ministry of Education
}

- Italian Association for Research on Cancer (AIRC)

- Italian National Research Council

- Dutch Ministry of Public Health, Welfare and Sports

- World Cancer Research Fund

- Swedish Cancer Society

- Swedish Scientific Council

- Regional Government of Skåne, Sweden

- Norwegian Cancer Society

- Research Council of Norway

\section{References}

I. Hackshaw AK, Law MR, Wald NJ: The accumulated evidence on lung cancer and environmental tobacco smoke. Bmj 1997, 3 I5(7 I I 4):980-988.

2. Vineis $P$, Alavanja M, Buffler $P$, Fontham E, Franceschi $S$, Gao YT, Gupta PC, Hackshaw A, Matos E, Samet J, Sitas F, Smith J, Stayner L, Straif K, Thun MJ, Wichmann HE, Wu AH, Zaridze D, Peto R, Doll R: Tobacco and cancer: recent epidemiological evidence. J Natl Cancer Inst 2004, 96(2):99-106.

3. IARC: Tobacco smoke and involuntary smoking. In IARC Monogr Eval Carcinog Risks Hum Volume 83. Lyon ; 2004: I-I 438.

4. Benowitz NL: Biomarkers of environmental tobacco smoke exposure. Environ Health Perspect 1999, 107 Suppl 2:349-355.

5. Riboli E, Hunt KJ, Slimani N, Ferrari P, Norat T, Fahey M, Charrondiere UR, Hemon B, Casagrande C, Vignat J, Overvad K, Tjonneland A, Clavel-Chapelon F, Thiebaut A, Wahrendorf J, Boeing $H$, Trichopoulos D, Trichopoulou A, Vineis P, Palli D, Bueno-De-Mesquita HB, Peeters PH, Lund E, Engeset D, Gonzalez CA, Barricarte A, Berglund G, Hallmans G, Day NE, Key TJ, Kaaks R, Saracci R: European Prospective Investigation into Cancer and Nutrition (EPIC): study populations and data collection. Public Health Nutr 2002, 5(6B): III3-II 24.

6. Vineis P, Airoldi L, Veglia P, Olgiati L, Pastorelli R, Autrup H, Dunning A, Garte S, Gormally E, Hainaut P, Malaveille C, Matullo G, Peluso M, Overvad K, Tjonneland A, Clavel-Chapelon F, Boeing H, Krogh V, Palli D, Panico S, Tumino R, Bueno-De-Mesquita B, Peeters P, Berglund G, Hallmans G, Saracci R, Riboli E: Environmental tobacco smoke and risk of respiratory cancer and chronic obstructive pulmonary disease in former smokers and never smokers in the EPIC prospective study. Bmj 2005, 330(7486):277.

7. EEA EEA: AirBase - the European Air quality dataBase. [http:/ lair-climate.eionet.europa.eu/databases/airbase/index html]. The Netherlands Environmental Assessement Agency (MNP) Bilthoven

8. Vineis P, Hoek G, Krzyzanowski M, Vigna-Taglianti F, Veglia F, Airoldi L, Autrup H, Dunning A, Garte S, Hainaut P, Malaveille C, Matullo G, 
Overvad K, Raaschou-Nielsen O, Clavel-Chapelon F, Linseisen J, Boeing $\mathrm{H}$, Trichopoulou A, Palli D, Peluso M, Krogh V, Tumino R, Panico S, Bueno-De-Mesquita HB, Peeters PH, Lund EE, Gonzalez CA, Martinez C, Dorronsoro M, Barricarte A, Cirera L, Quiros JR, Berglund G, Forsberg B, Day NE, Key TJ, Saracci R, Kaaks R, Riboli E: Air pollution and risk of lung cancer in a prospective study in Europe. Int J Cancer 2006, I I 9( I): I69-174.

9. Korn EL, Graubard BI, Midthune D: Time-to-event analysis of longitudinal follow-up of a survey: choice of the time-scale. Am J Epidemiol 1997, I 45(I):72-80.

10. Breslow NE, Day NE: Statistical methods in cancer research. Volume I - The analysis of case-control studies. In IARC Sci PubI Lyon, IARC; 1980:5-338.

II. Rothman KJ GS: Modern epidemiology. 2nd ed edition. Philadelphia , Lippincott-Raven; 1998.

12. Veglia F, Vineis P, Berrino F, Cerulli Ddel S, Giurdanella MC, Tumino R, Fiorini L, Sacerdote C, Panico S, Mattiello A, Palli D, Saieva C, Davico L: Determinants of exposure to environmental tobacco smoke in 21,588 Italian non-smokers. Tumori 2003, 89(6):665-668.

13. Tredaniel J, Boffetta P, Saracci R, Hirsch A: Non-smoker lung cancer deaths attributable to exposure to spouse's environmental tobacco smoke. Int J Epidemiol 1997, 26(5):939-944.

14. Brennan P, Buffler PA, Reynolds P, Wu AH, Wichmann HE, Agudo A, Pershagen G, Jockel KH, Benhamou S, Greenberg RS, Merletti F, Winck C, Fontham ET, Kreuzer M, Darby SC, Forastiere F, Simonato L, Boffetta P: Secondhand smoke exposure in adulthood and risk of lung cancer among never smokers: a pooled analysis of two large studies. Int J Cancer 2004, 109(I): |25-I3I.

15. Lee CH, Ko YC, Goggins W, Huang JJ, Huang MS, Kao EL, Wang HZ: Lifetime environmental exposure to tobacco smoke and primary lung cancer of non-smoking Taiwanese women. Int J Epidemiol 2000, 29(2):224-23I.

16. Tredaniel J, Boffetta P, Little J, Saracci R, Hirsch A: Exposure to passive smoking during pregnancy and childhood, and cancer risk: the epidemiological evidence. Paediatr Perinat Epidemiol 1994, 8(3):233-255.

17. Hecht SS, Ye M, Carmella SG, Fredrickson A, Adgate JL, Greaves IA, Church TR, Ryan AD, Mongin SJ, Sexton K: Metabolites of a tobacco-specific lung carcinogen in the urine of elementary school-aged children. Cancer Epidemiol Biomarkers Prev 200I, IO(II): I 109-I||16.

18. Whyatt RM, Jedrychowski W, Hemminki K, Santella RM, Tsai WY, Yang K, Perera FP: Biomarkers of polycyclic aromatic hydrocarbon-DNA damage and cigarette smoke exposures in paired maternal and newborn blood samples as a measure of differential susceptibility. Cancer Epidemiol Biomarkers Prev 200I, I 0(6):58I-588.

19. Somers CM, Yauk CL, White PA, Parfett CL, Quinn JS: Air pollution induces heritable DNA mutations. Proc Natl Acad Sci U S A 2002, 99(25): $15904-15907$.

20. Cohen AJ, Ross Anderson H, Ostro B, Pandey KD, Krzyzanowski M, Kunzli N, Gutschmidt K, Pope A, Romieu I, Samet JM, Smith K: The global burden of disease due to outdoor air pollution. J Toxicol Environ Health A 2005, 68(13-14): I30I-I 307.

21. Kunzli N, Kaiser R, Medina S, Studnicka M, Chanel O, Filliger P, Herry M, Horak F Jr., Puybonnieux-Texier V, Quenel P, Schneider J, Seethaler R, Vergnaud JC, Sommer H: Public-health impact of outdoor and traffic-related air pollution: a European assessment. Lancet 2000, 356(9232):795-80I.

22. Pope CA 3rd, Burnett RT, Thun MJ, Calle EE, Krewski D, Ito K, Thurston GD: Lung cancer, cardiopulmonary mortality, and long-term exposure to fine particulate air pollution. Jama 2002, 287(9): I|32-||4|.

23. Nyberg F, Gustavsson P, Jarup L, Bellander T, Berglind N, Jakobsson $R$, Pershagen G: Urban air pollution and lung cancer in Stockholm. Epidemiology 2000, I I (5):487-495.

24. Nafstad P, Haheim LL, Oftedal B, Gram F, Holme I, Hjermann I, Leren P: Lung cancer and air pollution: a 27 year follow up of 16209 Norwegian men. Thorax 2003, 58( I 2): 107I-1076.

25. Holgate S SJ Koren H, and Maynard R (eds.): Air Pollution and Health. In Air Pollution and Lung Cancer Edited by: Samet JM CAJ. London, Academic Press; 1999.

26. WHO: Air quality guidelines for particulate matter, ozone, nitrogen dioxide and sulfur dioxide - Global update 2005 -
Summary of risk assessment . WHO World Health Organization ; 2006.
Publish with Bio Med Central and every scientist can read your work free of charge

"BioMed Central will be the most significant development for disseminating the results of biomedical research in our lifetime. "

Sir Paul Nurse, Cancer Research UK

Your research papers will be:

- available free of charge to the entire biomedical community

- peer reviewed and published immediately upon acceptance

- cited in PubMed and archived on PubMed Central

- yours - you keep the copyright

Submit your manuscript here:

http://www.biomedcentral.com/info/publishing_adv.asp
BioMedcentral 